\title{
COMMUNITY PLANNING
}

\section{DIY Urbanism: Influences \& Impacts on Community Planning Steven Shuttle}

\begin{abstract}
'Do It Yourself' (DIY) urbanism is usually initiated by community members using a grassroots approach to change urban areas. Community planning involves making decisions about urban areas. This paper examines topics regarding DIY urbanism and community planning. Community engagement, neoliberalism and municipal support are key influences of DIY urbanism related to planning. DIY urbanism impacts the planner's role as well as the relationships between planners, communities and municipalities. Three Canadian examples of DIY urbanism are introduced, including the Urban Repair Squad, PARK(ing) Day, and CITYlab. Discussion focuses on the opportunities and potential challenges of DIY urbanism for planners to consider. Potential challenges include public safety and municipal liability. Recommendations for planners regarding DIY urbanism are provided. DIY urbanism can be beneficial if planners work collaboratively and focus on small scale, low cost improvements.
\end{abstract}

\section{INTRODUCTION}

Community planning involves decision-making on changes to urban areas. Throughout the history of community planning, members of the pubic have also created changes to places (Talen, 2015). Community members might take initiatives to 'do it themselves' instead of asking planners or municipalities. These community-led initiatives are part of 'do it yourself' or DIY urbanism, and could be described as individuals or groups taking localized initiatives to improve and make communities more livable (Douglas, 2013; Talen, 2015). DIY urbanism brings "renewed emphasis on participatory, people-centered urban planning" (Sawhney et al., 2015, 337). Examples of DIY urbanism include DIY street furniture, guerilla gardening and PARK(ing) Day (Finn, 2014). DIY urbanism, also referred to as guerilla urbanism or tactical urbanism, emphasizes small scale and creative initiatives to make communities more vibrant. As a result, these community-based DIY urbanism initiatives can provide critiques of the community planning processes for planners to consider.

This paper examines topics regarding DIY urbanism and community planning. First, it looks at how DIY urbanism influences community planning, and next, how it impacts the role of the planner. Key influences of DIY urbanism relate to community engagement, neoliberalism and municipal support. DIY urbanism impacts the relationships between planners, communities and municipalities. This paper will introduce three examples of DIY urbanism in Canada including the Urban Repair Squad, PARK(ing) Day and CITYlab, and also discuss the opportunities and potential challenges of DIY urbanism. Finally, recommendations for planners regarding DIY urbanism will be provided.

\section{COMMUNITY ENGAGEMENT}

Community planning is influenced by DIY urbanism as it is a change in traditional engagement. Community planning typically uses a 'top down' approach to engagement. The International Association of Public Participation on Community Engagement, or IAP2, considers a website or open house as a way to 'inform' the public and participatory decision-making as a 
form of engagement that aims to 'collaborate' with the public (IAP2, 2009). These current forms of 'top down' engagement might have limited abilities to build a community's engagement capacity (Sawhney et al., 2015). DIY urbanism can take an alternate approach by using grassroots or 'bottom up' community engagement. DIY urbanism can 'empower' communities, because it can give communities decision-making authority and improve community engagement capacity (IAP2, 2009). Following grassroots approaches from DIY urbanism can strengthen the civic values of communities (Pagano, 2013). This encourages communities seeking to build their engagement capacity to use DIY urbanism. Community members might favour DIY urbanism and grassroots approaches to engagement, while ignoring 'top down' attempts of planners. A potential outcome from grassroots approaches are communities with increased capacities for engagement, and sometimes paradoxically completely ignoring attempts by planners to provide meaningful participatory engagement (Finn, 2014). Contributions from dynamic DIY urbanism initiatives can positively influence community engagement in planning.

\section{NEOLIBERALISM}

DIY urbanism is a response to neoliberalism that influences community planning. In recent years, the role of community planning has decreased through adoption of neoliberal policies, as communities try to fill the gaps between their needs and reduced government services. DIY urbanism is also linked to the neoliberal process of gentrification (Douglas, 2014). Gentrification is a challenge for community planning because it brings revitalization or renovation to urban areas which can lead to displacement. The values reflected by DIY urbanism are often from white middle-class perspectives (Douglas, 2014). These values can fail to represent, or even oppose, the values of marginalized populations (Sibbald et al, 2015). DIY urbanism can enable these negative effects from neoliberalism to prevail (Douglas, 2014). However, the same could be said for community planning. Nonetheless, DIY urbanism can fill a gap between the reduced role of government, and the growing needs of communities. DIY urbanism can influence or complement community planning to overcome neoliberalism related challenges.

\section{MUNICIPAL SUPPORT}

The support from municipalities for DIY urbanism influences community planning. In their beginning stages, many DIY urbanism initiatives are not 'officially' supported by municipalities. Community planning involves public and private spaces and the boundaries between them. DIY urbanism looks at the idea of who is allowed to change urban spaces (Douglas, 2014). DIYers might think incorrectly that municipal support is not needed. Alternatively, this could mean that DIYers' attitudes and thinking might be in opposition to municipal standards.

Receiving official support by municipalities for certain DIY initiatives can have limited effectiveness on community planning. A municipality's support for DIY urbanism may actually hinder a community (Pagano, 2013). When DIY urbanism is used in development strategies, the capacity for community empowerment can be limited (Fabian \& Samson, 2016). This is because municipalities can favour encouraging private development over community empowerment. Another reason for the limited effectiveness of municipal support is related to community planning's bureaucracy. The bureaucracy in planning can create barriers to incorporating ideas from DIY urbanism into municipal planning (Talen, 2015). Overall, this can create a dilemma for DIYers, whether to seek a municipality's support, or not. In order to get municipal support, community members might be forced into making unwanted comprises. However, these 
compromises might be the same as those encountered in other forms of community planning. With support at the municipal level, DIY urbanism can be incorporated into the community planning process.

\section{IMPACTS ON THE PLANNER'S ROLE}

The role of the planner is impacted by DIY urbanism. When working with the public, planners need to build relationships with DIYers and the community. Planners can create meaningful relationships by engaging both place-based and network-based communities (Sawhney et al., 2015). Once relationships are created, planners and communities can collaborate on DIY urbanism. Planners need to recognize community planning is an ally, not an enemy, to DIY urbanism (Finn, 2014). This respect needs to be reciprocated by DIYers and community members. Planners should consider building relationships with DIYers in their community.

At the same time, planners should work with municipalities to bring DIY urbanism into community planning. Planners should recommend that municipalities work on permanently implementing successful DIY initiatives (Pagano, 2013). These DIY initiatives by citizens can provide short-term and low cost solutions for municipalities (Fabian \& Samson, 2016). If successful, a municipality should consider implementing rather than fighting an initiative.

The role of planner requires an approach to DIY urbanism that is both balanced and flexible. Part of the planner's role involves protecting the public from exposure to harm and municipalities from being liable. Planners need to balance flexibility and liability with DIY urbanism (Pagano, 2013). Planners need to balance community-based DIY urbanism with municipally-based plans. DIY urbanism can bring more community-based perspectives to temporary and permanent solutions (Fabian \& Samson, 2016). Ultimately, planners need to use discretion towards DIY urbanism. The planner's role is integrating DIY urbanism in ways that are "safe, equitable, effective and locally appropriate" (Finn, 2014, 395). The planner's role requires flexibility in balancing potential impacts of liability and livability from DIY urbanism.

\section{CANADIAN EXAMPLES OF DIY URBANISM}

DIY urbanism has impacted planning in Canadian communities. The Urban Repair Squad is a citizen group that alters communities in Toronto by creating guerilla bike lanes and signs (Douglas, 2014). The Urban Repair Squad takes an activist approach, operating without municipal support. Operating without support from the City of Toronto allows the Urban Repair Squad to build capacity for engagement with limited ability to directly influence community planning. The Urban Repair Squad's DIY urbanism impacts community planning through activism and disregard for the formal planning process. The Urban Repair Squad provides functional, forward thinking initiatives in a timely fashion, outside the formal planning process.

Another example of DIY urbanism is PARK(ing) Day. PARK(ing) is a worldwide event based on temporarily expressing ideas and initiatives of DIY urbanism (Finn, 2014). PARK(ing) Day events occur in several Canadian cities, allowing community members or DIYers to create a smallscale, temporary installation within the area of a parking stall. Although this event has some constraints, it allows DIY urbanism to be expressed in an accessible way. Part of PARK(ing) Day's impact is allowing community members, planners and municipal officials the ability to interact with DIY urbanism. Planners could further refine or potentially implement successful initiatives. 
The small scale and temporary DIY initiatives from PARK(ing) Day can create vibrancy and exciting spinoff effects.

The CITYlab is an example of a municipality's attempt at incorporating and fostering DIY urbanism (City of Edmonton, 2016). On one hand, the CITYlab offers support to communities for creating DIY initiatives. On the other hand, municipal bureaucracy may potentially reduce the capacity for DIY initiatives by the CITYlab to create community empowerment. The CITYlab shows an attempt by the City of Edmonton to work with DIYers and community members. In terms of community engagement, as defined by IAP2 (2009), the CITYlab might be considered to 'collaborate' with the community by implementing successful DIY initiatives. Some of the CITYlab's successful initiatives include Rainbow Crosswalks, the Whyte Avenue Alley Project and Incline to Include. These initiatives illustrate a municipality's attempt to use DIY urbanism ideas in the planning process.

\section{OPPORTUNITIES AND CHALLENGES OF DIY URBANISM}

DIY urbanism presents opportunities and potential challenges to planners. One benefit of DIY urbanism is improving a community's engagement capacity through 'bottom up' approaches (Pagano, 2013). Additionally, DIY urbanism can fill the gaps between the increasing needs of communities and the decreased role of neoliberal governments. At the same time, DIY urbanism can allow planners and communities to collaborate (Finn, 2014). Most importantly, DIY urbanism can use small-scale and temporary initiatives to make communities more vibrant and livable. These opportunities can outweigh potential pitfalls that planners may experience when working with DIY urbanism. One potential challenge is that DIY urbanism can create a paradox of communities ignoring engagement by planners (Finn, 2014). DIY urbanism can fail to represent marginalized populations, while favouring white middle-class values (Douglas, 2014; Sibbald et al, 2015). DIY urbanism can make the public believe that support from municipalities is not necessary. But, this lack of municipal support for DIY urbanism can limit the ability to improve community engagement capacities (Fabian \& Samson, 2016). Given their dynamic forms, DIY urbanism initiatives can create liability for municipalities (Pagano, 2013). These challenges can be mitigated by planners and the community planning process. Planners should become aware of the opportunities and potential challenges when working with DIY urbanism.

\section{RECOMMENDATIONS FOR PLANNERS}

Planners have a significant role in community planning and DIY urbanism. To build capacity for engagement, planners may consider collaborating with communities to use elements of DIY urbanism. This collaboration helps prevent communities from ignoring planners or being hindered by lack of municipal support. It is important for planners to ensure DIY urbanism initiatives reflect community values and include marginalized populations. When working with DIY initiatives planners need to keep in mind issues such as public safety and municipal liability. Planners can create vibrancy by allowing or hosting small scale events focused on DIY urbanism, such as PARK(ing) Day. Planners may consider working towards getting municipal support to permanently implement successful DIY initiatives.

\section{CONCLUSION}

Influences and impacts of DIY urbanism on community planning were examined. Community engagement, neoliberalism and municipal support are key influences of DIY urbanism 
related to planning. DIY urbanism impacts the planner's role and affects relationships between planners, communities and municipalities. Three Canadian examples of DIY urbanism were introduced, including the Urban Repair Squad, PARK(ing) Day, and CITYlab. Discussion focused on the opportunities and potential challenges of DIY urbanism for planners to consider. Recommendations for planners regarding DIY urbanism were provided. DIY urbanism may be of significant use to planners if balanced and flexible approaches are taken. The impacts of DIY urbanism can be beneficial if planners collaborate with communities to find small scale, low cost ways to improve communities.

\section{REFERENCES}

City of Edmonton. (2016). CITYlab. Retrieved December 08, 2016, from https://www.edmonton.ca/citylab.aspx

Douglas, G. C. (2014). Do-It-Yourself Urban Design: The Social Practice of Informal 'Improvement' Through Unauthorized Alteration. City \& Community, 13(1), 5-25. doi:10.1111/cico.12029

Fabian, L., \& Samson, K. (2016). Claiming participation - a comparative analysis of DIY urbanism in Denmark. Journal Of Urbanism, 9(2), 166. doi:10.1080/17549175.2015.1056207

Finn, D. (2014). DIY urbanism: implications for cities. Journal Of Urbanism, 7(4), $381-398$. doi:10.1080/17549175.2014.891149

International Association of Public Participation on Community Engagement. (2009). IAP2 Spectrum of Public Engagement (ICE) - SPARC. Retrieved October 20, 2016, from http://www.sparc.bc.ca/1ap2-spectrum-ofpublic-engagement

Pagano, C. (2013). DIY urbanism: property and process in grassroots city building. Marquette Law Review, (2), 335389.

Sawhney, N., de Klerk, C., \& Malhotra, S. (2015). Civic Engagement through DIY Urbanism and Collective Networked Action. Planning Practice \& Research, 30(3), 337-354.

Sibbald, S. L., Graham, R., \& Gilliland, J. (2015). The public health response to 'do-it-yourself' urbanism. Global Health Promotion, 0(0), 1-3.

Talen, E. (2015). Do-it-Yourself Urbanism: A History. Journal Of Planning History, 14(2), 135. doi:10.1177/1538513214549325 